\title{
Commercialization Process of Disruptive Innovations in Corporate Ventures and Spinoff Companies: A Comparison
}

Javier Nieto Cubero ${ }^{*}$, , Saheed Adebayo Gbadegeshin², Carolina Consolación Segura ${ }^{3}$

${ }^{1}$ EINA University Center of Design and Arts, Autonomous University of Barcelona, Design Processes Research Group, 08017, Spain

${ }^{2}$ Turku School of Economics, University of Turku, Department of Management and Entrepreneurship, 20014, Finland \& DeGesh

Institute of Technology and Entrepreneurship; 20002, Nigeria

${ }^{3}$ ETSETB, Polytechnic University of Catalonia, Department of Management, 08034, Spain

A R T I C LE INFO

Article history:

Received: 11 January, 2020

Accepted: 22 March, 2020

Online: 14 April, 2020

Keywords:

Commercialization

Transition Management

Disruptive Innovations

Ambidexterity

Corporate Venturing

Spin-off

\begin{abstract}
A B S T R A C T
One of the most critical challenges that large companies, small enterprises and research institutes face, when commercializing their innovations, is the transfer process at the moment of scaling up. These organizations often transfer their innovation to either existing business units or create a new business entirely. The process of transferring innovations to an existing unit is known as corporate venture, while creating a new business is called spinoff. Both processes have been studied separately, but not yet together and from different business sectors and countries. In order to understand both processes, this article compares the commercialization of disruptive innovations from these sectors: electronics, information technology, telecommunications, engineering, healthcare, biotechnology or research equipment. The article used multiple case study methodology from commercialization projects carried out in large, small and medium-sized companies and research institutes based in Spain, Germany, UK and Finland. The findings showed that certain activities needed to be done at pre-transition /commercialization, transition/commercialization, and post-transition/commercialization phases to reach a successful transition. Furthermore, the study provides similarities between the corporate venture and spinoff approaches that include team formation, network development and getting the commitment from the company and stakeholders. Additionally, the article outlines divergences between the approaches which consist of innovation readiness, knowledge management or the activities of the post-transition phase. The article also provides insight for innovation scholars, commercialization practitioners, and business enterprises. Therefore, the article contributes to the commercialization of disruptive innovations.
\end{abstract}

\section{Introduction}

In today's fast-paced technologically based environments, to keep long-term competitiveness, companies need to introduce disruptive and incremental innovations to markets [1,2]. The disruptive innovations need to be commercialized as it is argued by the scholars [3]. Unfortunately, the commercialization of these innovations has not been thoroughly studied [4], despite its importance within the innovation process [5]. Disruptive innovations are challenging to commercialize by both established enterprises and new businesses (specifically spinoffs). One of the

*J. Nieto Cubero, P. Santa Eulalia 25, 08017 Barcelona, +34 653560568, jnietoc@eina.cat

www.astesj.com

https://dx.doi.org/10.25046/aj050278 most critical challenges that mature corporations face at the commercialization phase is the transition of an innovation project to their business units for scaling up the project. Similarly, spinoff companies meet obstacles related to organizational factors when commercializing their disruptive innovation [6].

Thus, the corporate venture could be described as the exploration and exploitation of new technologies or products. It is detached from the corporate parent to avoid organizational inelasticity. Additionally, the term "corporate venture" could refer to "spin-in" according to [7]-[9]. Moreover, the commercialization of innovations by establishing a new enterprise is known as spinoff. Spinoff is defined as the creation of a new company to 


\section{J. N. Cubero et al. / Advances in Science, Technology and Engineering Systems Journal Vol. 5, No. 2, 621-634 (2020)}

commercialize the business potential of a technology or innovation.

Currently, literature has explained the corporate venture process from many different perspectives, such as the corporate parent [10] or the corporate venture [11]. However, it is noted in the literature that there is a limited discussion on the venture transition at the moment of scaling up the innovation. Specifically, there is a limited scholarly discussion on how to design the transition process. Similarly, there is not yet a model that discusses activities needed for the successful transition of the corporate venture into the established company businesses [12] to reach the full commercialization of the innovation.

The existing literature also has explained the spinoff process from the parent organization and the academic entrepreneur's perspective. Nevertheless, few studies have focused on the commercialization process of the spinoff and how the innovation is transformed into a marketable product or service via the spinoff. Therefore, there is a need for in-depth knowledge of the commercialization process of spinoff [6].

Furthermore, ambidextrous literature has not yet provided a better explanation for the transferring of disruptive innovations in corporate entrepreneurship environments, by spin-in (corporate venture) or spinoff. Lastly, the current literature does not either provide a comparison among corporate ventures and spinoffs in their process of commercialization.

Therefore, the purpose of this article is to provide a better understanding of the commercialization process of disruptive innovations in the context of corporate venture and spinoff. It aims to provide critical factors and activities to perform in order to reach a successful scaling up innovation in these environments. To achieve these goals, it employed a qualitative research method.

The article also provides a comparison of the process of commercialization between corporate ventures and spinoffs in order to learn about the challenges they face in the commercialization process. The article offers both theoretical and practical knowledge to discourse on the commercialization process.

The rest of the article is organized as follows; Section 2 presents the theoretical background about the commercialization process in the corporate venture and spinoff, section 3 details the employed research method, section 4 presents the results obtained from the empirical studies, and section 5 presents discussion and conclusions. The last section presents contributions and limitations of the article as well as provides avenues to future research.

\section{Theoretical Background}

Disruptive innovations are new technologies, techniques or knowledge that generate market and technological breakthroughs on macro and micro levels. These innovations embody new technology that causes a new market environment or generates different customer behaviors. These innovations are affected by Scurve(s): market, technology, or both, during their introduction to the marketplace $[13,14]$. More specifically, disruptive innovations are radical, and they distort existing ecosystems [15]. Thus, the disruptive innovation changes the relations among firms and customers, modifies marketplace, overtakes current products and reconfigures the innovator's resources $[16,17]$.

The corporate venture is often used to improve competitive positioning and transform corporations, their markets, and industries. It can also be used as opportunities to exploit valuecreating innovations. The corporate ventures are startup-like structures that are idea-wise rooted in an established company. They are commonly used in exploration processes of disruptive innovations.

Thus, the corporate venture is, at this moment, described as the exploration and exploitation of new technologies or products, detached from the company's exploitation activities in an "incubation" cell structure that avoids organizational inelasticity and provokes resources and organizational renewal [18]-[20]. The corporate is notably essential when the innovation is still in an early phase, characterized by high uncertainties. Typically, the venture should be transferred to an existing business unit from the corporate parent creating profits within the firm. Meanwhile, the relationships between new corporate ventures and existing business units generate conflicts [21,22]. If this conflict is escalated, the incorporation of corporate venture into an existing corporate unit could be harmful to the development of the innovation and could also find hostility in the receiving team [23].

Notably, the corporate venture is different from intrapreneurship, which is described as infusing the mindset of entrepreneurs in the company's team and thus generating an innovative atmosphere within the company, as enunciated by [24]. Similarly, the corporate venture is different from the spinoff. While the corporate venture is a structurally separated unit with resources to manage innovation projects from idea to commercialization, the spinoff is an entirely new business created to develop and exploit the potential of the innovation.

The spinoff is defined as the generation of a new business to reach profits of new technology or innovation. This new business formation is attained by transferring innovation and other resources (e.g., intellectual property and human) from the originating organization. The originating organization consists of companies, universities or tertiary institutions and research institutes [25]. The spinoff also refers to a new firm that is established to commercialize business opportunities for a new technology that is developed by the research organizations [26]. Additionally, it could be a new company founded fundamentally to exploit an intellectual property that is developed by a university [27]. The spinoff is otherwise known as an academic spinoff, research-based spinoff or new technology-based firm.

\subsection{Corporate Venture (CV)}

This article focuses on the transition phase of disruptive innovations, and particularly on the transference of innovations to a receiving business unit of the corporate parent.

Usually, a split exists among innovation teams and existing business units, as stated by [13]. Supported by research from [19], these scholars point out that there is not a defined process or methodology to guarantee the delivery of the innovation projects from research and development (R\&D) at an acceptable level to the business unit before reaching the scaling-up phase. It has been 


\section{J. N. Cubero et al. / Advances in Science, Technology and Engineering Systems Journal Vol. 5, No. 2, 621-634 (2020)}

studied in literature through different perspectives, and it is described in the following paragraphs.

Uncertainties perspective: the scholars $[28,13]$ outlined four kinds of uncertainties: technical, market-concerned, organizational and resources-based. Due to these uncertainties, disruptive innovations are usually substituted by incremental innovations [29]. Technical uncertainty includes the scientific knowledge base, technical feasibility and manufacturing process. The marketconcerned uncertainty comprises the understanding of the new customer value, in relation to the existing competition [13]. The organizational uncertainty involves the organizational and managerial difficulties at integrating a disruptive innovation while pursuing exploitation activities. This uncertainty is mainly caused by unsupportive top management [10] or by the misfit among the corporate business unit and the innovation team [16]. The last uncertainty is resource-based. It addresses all the issues of acquisition of the resources to get successful exploitation of the disruptive innovation [30,31].

Technology readiness: the research from [32] offers an assessment tool to convert a technology invention into a profitable business, and the study of [33] provides a global view about the Technology Readiness Levels (TRL's). Nonetheless, these scholars only approach the phenomenon under a technology uncertainty perspective.

Ambidexterity perspective: the ambidexterity literature [20] introduces the construct of separated units for exploration and commercialization, coordinated at the top management level. This structural detachment guarantees that the exploration activities are preserved from the bureaucracies, managerial routines, and the culture of exploitation [34]. The works from [35,36,20] have enunciated that the detachment among exploration and exploitation activities foster the benefits of both [37]. Similarly, the work of [36] argues that ambidextrous organizations require methodologies to activate, organize and incorporate separated exploration and exploitation units in organizations.

Separation is mainly required to emphasize on disruptive exploration. Nevertheless, the detachment of these units from the corporate parent is a necessary yet insufficient condition for ambidexterity [38].

Notwithstanding the acknowledged obstacles for venture transition, the extant literature on the process of transference to an existing business is relatively scarce [39]. Research on integration mechanisms is still needed, and as [36] underlined, is required more research about how "transition should be done."

Championship perspective: many different scholars enunciate the relevance of having the support of a champion not only in the innovation team but also at senior management level [40,41]. Several studies also have studied the role of senior management in fostering integration and enhance synergies between exploration and exploitation units [12,35]. Moreover, the likelihood of transition success is also raised if a champion appears in the receiving unit $[12,13]$ or if it has the support of an informal network [31]. Clear and transparent communication is critical to recognize the right supporters within the corporate parent [29]. [11] also stresses the relevance of exchanges within corporations not only at a management level but also between business units and other stakeholders of the firm.

Regarding CV, the disruptive innovation cell's managers are needed to smooth the integration of the project into the business unit by demonstrating the feasibility of the innovation, making concepts and benefits tangible and finding latent needs from customers.

\subsubsection{Corporate ventures transition phases}

The work from [12] distinguishes three stages in the transition from a separated venture to a one that is integrated into the established corporate structure: the pre-transition, the transition, and the post-transition phase. The pre-transition phase is described as a stage to develop connecting and learning activities between the CV and the parent business. During the transition phase, the hand-over moment takes place, and the venture is transferred to the corporate organization, while the post-transition phase is defined as the stage when the venture is incorporated in the established organization.

\subsubsection{Specific activities in transition phases in corporate ventures}

A summary of the existing literature on activities to perform in the commercialization process and activities to be performed within each phase of transition is displayed in Table 1.

\subsection{Spinoff (CSO)}

There are two approaches to the spinoff. The first approach is a planned spin-off. The planned spin-off is predetermined and is based on the plan of a parent organization. The parent organization often states that a new venture would stem from the commercialization activities of their project. The second approach is a spontaneously occurring spinoff. It happens when a new business venture is created unexpectedly. Generally, this spin-off does not get total support from the parent organization [42]. Commercializing innovation through a spinoff has been studied through different approaches. They are described in the following paragraphs.

Strategic perspective: From the strategic viewpoint, the scholars state that commercializing an innovation requires different strategies, orientations, and decisions. According to [43], there are three strategies: early adoption, adoption network configuration, and mainstream adoption. These authors explained that early adoption strategy is the method when a commercializing team adopts to create awareness, stimulate and motivate people to have a positive attitude towards the new product. Similarly, the authors stated that the adoption of a network configuration is the ability of the team to enable early buyers to be strong supporters of the product. Likewise, the authors mentioned that the mainstream strategy is the decision and effort of the team to transfer a configured network to the primary market. Still, from the strategic perspective, commercializing an innovation also requires different decisions to be made. [44] found that world-leading companies, well-known for their innovation commercialization, made critical decisions by placing commercialization as one of their highest priorities, establishing measurable objectives for proper management, and developing sufficient and essential competencies. 
Table 1. Corporate venture activities in commercialization phases

\begin{tabular}{|c|c|c|c|}
\hline $\begin{array}{c}\text { Transition } \\
\text { Phase }\end{array}$ & Category & $\begin{array}{c}\text { Specific } \\
\text { Activities }\end{array}$ & Scholars \\
\hline \multirow[t]{3}{*}{$\begin{array}{l}\text { Pre- } \\
\text { Transition }\end{array}$} & $\begin{array}{l}\text { Innovation project } \\
\text { preparation for } \\
\text { scale-up }\end{array}$ & $\begin{array}{l}\text { Transition } \\
\text { readiness } \\
\text { assessment } \\
\text { Transition } \\
\text { team } \\
\text { Transition } \\
\text { plan }\end{array}$ & $\begin{array}{l}\text { O'Connor, Hendricks and } \\
\text { Rice (2002), Rice, Leifer } \\
\text { and O'Connor (2002) and } \\
\text { van Burg et al. (2012). } \\
\text { Rice, Leifer and O'Connor } \\
\text { (2002) and van Burg et al. } \\
(2012) \text {. } \\
\text { Kanter et al. (1991) Rice, } \\
\text { Leifer and O'Connor (2002). }\end{array}$ \\
\hline & $\begin{array}{l}\text { Conditions for } \\
\text { validation }\end{array}$ & $\begin{array}{l}\text { Achievement } \\
\text { of first sales } \\
\text { and running of } \\
\text { pilot projects }\end{array}$ & Nieto (2018). \\
\hline & $\begin{array}{l}\text { Early-relations } \\
\text { with the potential } \\
\text { receiving business } \\
\text { units }\end{array}$ & $\begin{array}{l}\text { Training and } \\
\text { personal } \\
\text { exchange } \\
\text { Cross- } \\
\text { functional } \\
\text { interfaces } \\
\text { Liaison } \\
\text { channeling } \\
\text { and network } \\
\text { building } \\
\text { Horizontal } \\
\text { interactions } \\
\text { between teams }\end{array}$ & $\begin{array}{l}\text { van Burg et al. (2012). } \\
\text { Jansen et al. (2009). } \\
\text { Gassman et al. (2012). } \\
\text { Raisch and Tushman } \\
\text { (2016). }\end{array}$ \\
\hline \multirow[t]{2}{*}{ Transition } & Transition time & $\begin{array}{l}\text { Transference } \\
\text { after achieving } \\
\text { first sales } \\
\text { Laying the } \\
\text { groundwork } \\
\text { for a } \\
\text { significant } \\
\text { market }\end{array}$ & $\begin{array}{l}\text { van Burg et al. (2012). } \\
\text { Rice, Leifer and O'Connor } \\
(2002) \text {. }\end{array}$ \\
\hline & $\begin{array}{l}\text { Knowledge } \\
\text { management }\end{array}$ & $\begin{array}{l}\text { Transfer of } \\
\text { the R\&D team } \\
\text { to the } \\
\text { receiving } \\
\text { business unit }\end{array}$ & Nieto (2018). \\
\hline $\begin{array}{l}\text { Post- } \\
\text { transition }\end{array}$ & $\begin{array}{l}\text { Specification of } \\
\text { suitable KPI's in } \\
\text { the business unit }\end{array}$ & $\begin{array}{l}\text { Post transition } \\
\text { autonomy. } \\
\text { Performance } \\
\text { metrics }\end{array}$ & van Burg et al. (2012). \\
\hline
\end{tabular}

Marketing perspective: The scholars, from the marketing viewpoint, seem to focus on the marketization of the disruptive innovation through innovation, according to [2]. The high technologies make use of disruptive innovations. Thus, marketing scholars state that innovation would be successful if the final consumers can accept them. Examples of prominent scholars in this group are [45,46]. To reinforce the credibility of this viewpoint, [47] argued that innovation would be successfully commercialized if it could be market oriented. This scholar stated that commercialization must start with the market and end with it. In a similar view, [48] added that the commercialization should focus on the substitute products/services as well as on the functionality of commercializing products concerning its price. However, marketization is cumbersome, tedious and full of risks. According to [49], six challenges are awaiting the commercializers of disruptive innovation. The scholar stated that they marketconcerned uncertainty, technological uncertainty, the inconsistency of new products in a complex multi-component system, difficulty in developing networks, the problem of ecosystem complexities and competition, and inherent risks of choice-making (especially with multiple and interdependent product-market options).

Skills perspective: From the skills perspective, the scholars emphasize how the commercialization should be accomplished. Examples of scholars in this perspective are [50,51]. [51] emphasized that innovation can reach the market successfully if the commercialization team can: (1) acquire and possess sufficient technological knowledge, (2) develop the innovation into a product which can be mass-produced, (3) establish commercialization process and relate it to growth strategy, (4) adhere to their process as a learning path, and coordinate and maintain a good network. Furthermore, [52] stressed that, though focused on the strategy, marketing skills are crucial for their successful commercialization. To assist practitioners, these scholars proposed market and user research tools, which include customer ethnography, emphatic designs, lead-user processes, investigating users, and the targeting of new markets.

Considering all these perspectives, the question of "what one has to do in commercializing disruptive innovation successfully in terms of activities" is fragmented depending on the perspective approach.

\subsubsection{Spinoff commercialization phases}

When commercializing disruptive innovations through a spinoff, three phases are recognized, as acknowledged by [53][56]. These phases are pre-commercialization, commercialization and post-commercialization. The pre-commercialization is the stage where any activity aiming at transforming new technology into products and services is done. The commercialization phase contains all the transformation efforts. The post-commercialization includes any attempt to make new products or services sustain market share at a profit for its commercializing team and companies.

\subsubsection{Specific activities in commercialization phases in spinoffs}

Based on the above grouping, the previous works describe the activities to perform in each phase and they are summarized in the following Table 2 .

\subsection{Relationship between CV's and CSO's in the commercialization stage.}

The work from [57] discussed the role and relevance of internal corporate venturing and spinoffs as means to corporate renewal and to improve competitive positioning.

Meanwhile, similarities and differences between different corporate entrepreneurship structures have been researched by scholars, for instance between Startups and CV's, as enunciated by 


\section{J. N. Cubero et al. / Advances in Science, Technology and Engineering Systems Journal Vol. 5, No. 2, 621-634 (2020)}

Table 2. Spin-off activities in commercialization phases

\begin{tabular}{|c|c|c|}
\hline $\begin{array}{c}\text { Commercialization } \\
\text { Phase }\end{array}$ & Specific Activities & Scholars \\
\hline \multirow[t]{3}{*}{$\begin{array}{l}\text { Pre- } \\
\text { commercialization }\end{array}$} & $\begin{array}{l}\text { Basic and applied science } \\
\text { /discovery technology/ } \\
\text { initiation / }\end{array}$ & $\begin{array}{l}\text { Maine and Garnsey } \\
\text { (2007), AbdRahima et al. } \\
(2015), \text { Amadi-Echendu } \\
\text { and John, (2008), and } \\
\text { Pietzsch et al. (2009). }\end{array}$ \\
\hline & $\begin{array}{l}\text { Formulation/identification } \\
\text { of technological } \\
\text { opportunity/ Application } \\
\text { idea initial technical and } \\
\text { economic viability }\end{array}$ & $\begin{array}{l}\text { Maine and Garnsey } \\
\text { (2007), AbdRahima et al. } \\
\text { (2015), Amadi-Echendu } \\
\text { and John (2008). }\end{array}$ \\
\hline & $\begin{array}{l}\text { Reviewing the technology } \\
\text { / Application }\end{array}$ & $\begin{array}{l}\text { Eldred and McGrath } \\
\text { (1997) and Amadi- } \\
\text { Echendu and John (2008). }\end{array}$ \\
\hline \multirow[t]{10}{*}{$\begin{array}{l}\text { On- } \\
\text { commercialization }\end{array}$} & $\begin{array}{l}\text { Having a development } \\
\text { team and organizing a } \\
\text { senior review team / } \\
\text { formalizing } \\
\text { commercialization project }\end{array}$ & $\begin{array}{l}\text { Eldred and McGrath } \\
\text { (1997) and Rogers et al. } \\
\text { (2004). }\end{array}$ \\
\hline & $\begin{array}{l}\text { Formalizing } \\
\text { commercialization project }\end{array}$ & Rogers et al. (2004). \\
\hline & $\begin{array}{l}\text { Scanning and creation of } \\
\text { potential } \\
\text { alliances/identification of } \\
\text { specific need of target } \\
\text { market/ conducting of } \\
\text { preliminary material } \\
\text { investigation / }\end{array}$ & $\begin{array}{l}\text { Maine and Garnsey } \\
\text { (2007) and Chen and } \\
\text { Panda (2005). }\end{array}$ \\
\hline & $\begin{array}{l}\text { Designing, building and } \\
\text { testing of } \\
\text { prototypes/designing and } \\
\text { prototyping/design and } \\
\text { development / } \\
\text { Developing prototypes } \\
\text { and integrating the } \\
\text { prototype into existing } \\
\text { products/incubation }\end{array}$ & $\begin{array}{l}\text { Rogers et al. (2004), } \\
\text { Maine and Garnsey } \\
\text { (2007), Pietzsch et al. } \\
\text { (2009) and Chen and } \\
\text { Panda (2005). }\end{array}$ \\
\hline & $\begin{array}{l}\text { Development of } \\
\text { technological } \\
\text { product/service }\end{array}$ & $\begin{array}{l}\text { AbdRahima et al. (2015) } \\
\text { and Amadi-Echendu and } \\
\text { John (2008). }\end{array}$ \\
\hline & $\begin{array}{l}\text { Customer testing and } \\
\text { experimentation }\end{array}$ & $\begin{array}{l}\text { Maine and Garnsey } \\
(2007) \text {. }\end{array}$ \\
\hline & $\begin{array}{l}\text { Verification of relating } \\
\text { policies/ evaluation of } \\
\text { make/buy } \\
\text { decision/development of } \\
\text { the pilot plant, }\end{array}$ & $\begin{array}{l}\text { Rogers et al. (2004) and } \\
\text { Maine and Garnsey } \\
(2007) .\end{array}$ \\
\hline & $\begin{array}{l}\text { Deciding on channels of } \\
\text { distribution }\end{array}$ & Rogers et al. (2004). \\
\hline & $\begin{array}{l}\text { Final validation / final } \\
\text { customer testing }\end{array}$ & $\begin{array}{l}\text { Pietzsch et al. (2009) and } \\
\text { Maine and Garnsey } \\
(2007) \text {. }\end{array}$ \\
\hline & $\begin{array}{l}\text { Developing a structured } \\
\text { commercialization } \\
\text { method / developing } \\
\text { structured processes }\end{array}$ & $\begin{array}{l}\text { Eldred and McGrath } \\
\text { (1997) and Chen and } \\
\text { Panda (2005). }\end{array}$ \\
\hline $\begin{array}{l}\text { Post- } \\
\text { commercialization }\end{array}$ & $\begin{array}{l}\text { Product launching and } \\
\text { post-launching } \\
\text { assessment/market, and } \\
\text { acceleration }\end{array}$ & $\begin{array}{l}\text { Pietzsch et al. (2009), } \\
\text { Amadi-Echendu and John } \\
\text { (2008). }\end{array}$ \\
\hline
\end{tabular}

[58], USO's (university spinoffs) and CV's, as stressed by [59], USO's and CSO's, as outlined by [60,61], or between IV's (independent ventures) and CV's [62]. Similarly, under the perspective of the leaders of the innovation units, commonalities and divergencies between corporate entrepreneurs and spinoff entrepreneurs have been discussed by [63].

The previous works show that the commercialization process of the corporate venture consists of pre-, transition, and posttransition. The phases are similar to the spinoff, which include precommercialization, commercialization and postcommercialization. The previous literature also states the different activities to be done at each phase. However, there is missing knowledge of the commercialization process of disruptive innovation via the corporate venture and spinoff. Thus, this article seeks to provide to the following research questions:

- What are the key activities that facilitate managing the transition and commercialization of disruptive innovations in corporate ventures and spinoffs?

- What are the differences and similarities in the process of commercialization between a corporate venture and a spinoff?

- Do corporate ventures face the same problems that spinoffs are confronted with?

\section{Research design}

\subsection{Methodology approach}

In order to answer the research questions, a multiple case study approach has been selected. Case study research involves the examination of a phenomenon in its natural environment. The case study method is specifically appropriate to research new field areas, with a focus on "how" or "why" questions, related to a contemporary set of events. The study of multiple cases is usually considered as a more robust method, as it provides the observation and analysis of a situation in different settings. The multi-case method enables an understanding of the phenomenon beyond each project context and increases generalizability [64]. There were two sets of empirical data in this research. The first set was gathered for corporate ventures and the second for spinoffs.

\subsubsection{Corporate venture case selection and data collection}

Potential disruptive innovation projects were evaluated according to criteria provided by the definitions of [65], who uses disruptive to describe innovations that could occur in a macro-level as well as micro-level contributions.

Based on the above criteria and according to [66], who state that theoretical sampling is a means to reach a high gain of insight, twelve corporate venture transition processes were selected. Nine of those samples found an internal existing business unit of the corporate parent to be integrated in. One of them found an external firm, and two projects employed a dual destination model to an internal business unit as well as to an external company. Eight of the samples have been successful in the transition process, and the other four were failure cases. The cases are presented in Table 3.

The companies have been named (Telco Co, FMCG Co, Appliances $\mathrm{Co}$, Financial Co, Engineering $\mathrm{Co}$ ). We also define the 
name of the chosen projects as Tel1, Tel2, Tel3, Tel4, Tel5, Tel6, Fast1, App1, App2, Fin1, Eng 1, and Eng2. The real names of companies and projects are not displayed due to the confidentiality research agreements.

For the sample, data were collected through interviews with innovation unit managers and corporate innovation managers to achieve different perspectives on the success of the project, conflicts, key issues and evolution of the project transition, reaching a variety of insights. The research carried out 26 double interviews. Each interview took 1 to $1,30 \mathrm{hrs}$. Long. The interviews were performed in two rounds. The first round, to understand the overall context of the project and company and the second round to obtain a deeper understanding of each project's details. During the conduction of the interviews, nevertheless, the interview guideline was regularly updated and enriched to be adapted to the insights obtained after the previously analyzed project. The documentation was complemented with secondary data about each project obtained from the corporate company.

\subsubsection{Spinoff case selection and data collection}

According to the criteria mentioned above, twenty spin-off companies were selected. They were chosen according to the type of disruptive innovations. Also, these companies were founded by serial entrepreneurs and business advisors. The details of the projects are also presented in Table 4 . The spin-off projects were denoted by COY 1 to COY 20, respectively. The cases are presented in Table 4. Data were obtained through interviews. The study participants were contacted via email and telephone calls. After booking a date and venue, they were sent interview questions with themes. After a few weeks, the interviews were conducted. Each interview took more than 1 hour. All interview processes were following the qualitative research guideline provided by [67][71].

\subsection{Data analysis}

Qualitative analysis needs a different approach than the quantitative analysis because of the nature of the collected data, mostly textual and descriptive. The research is focused on the process of transition and commercialization, and more specifically, on the tasks developed to overcome the challenges found during the process. The information obtained from interviews was transcripted and later analyzed by using open coding [72] to recognize patterns in transition activities and critical problems influencing the transference and commercialization of the innovation projects. The following step was the axial coding, identifying relationships between categories, organizing them hierarchically with interconnections and sub-categories. The last step was selective coding to produce a theory and recognize core categories. NVivo11 software was used for helping in the analysis and codification of qualitative data obtained at interviews. It is a software that supports data management, in the process of exploration and coding that is not linear, but iterative.

Similar patterns responding to the formulated research questions were codified, defining the main tasks to perform in order to overcome commercialization problems and barriers in corporate ventures and spinoffs. The theory that emerged from the interviews was compared with the existing literature leading to specific conclusions displayed in the following sections. Discovered similarities increase the validity of the findings and link old and new theory. Emerging differences show opportunities for new concepts and avenues for future research.

Table 3. Summary of corporate venture cases and interviewed profiles

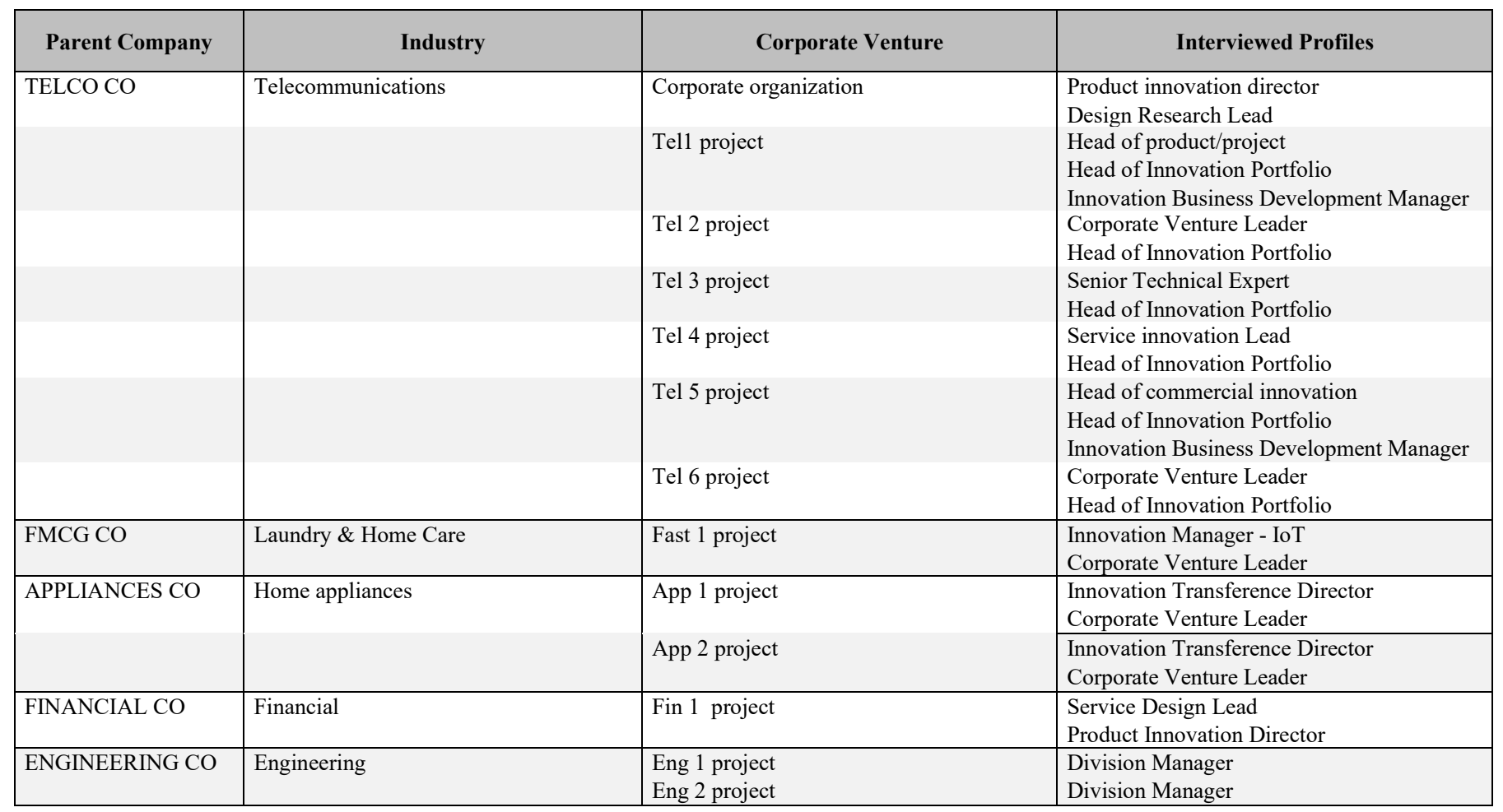


Table 4. Summary of spinoff cases and interviewed profiles

\begin{tabular}{|c|c|c|}
\hline Companies & Industry & Interviewed profiles \\
\hline Coy 1 & Electronics & $\begin{array}{l}\text { CEO } \\
\text { Chief Engineer }\end{array}$ \\
\hline Coy 2 & Environment Tech & $\begin{array}{l}\text { CEO } \\
\text { Chief Engineer }\end{array}$ \\
\hline Coy 3 & Healthcare Equipment & $\begin{array}{l}\text { CEO } \\
\text { Head of Venture Capital } \\
\text { IPR Manager }\end{array}$ \\
\hline Coy 4 & Research Equipment & $\begin{array}{l}\text { CEO } \\
\text { Business developer } \\
\text { Head of Venture Capital }\end{array}$ \\
\hline Coy 5 & Research Equipment & CEO \\
\hline Coy 6 & Electronics & \begin{tabular}{|l|} 
CEO \\
Chief Engineer
\end{tabular} \\
\hline Coy 7 & Research Instrument & $\begin{array}{l}\text { CEO } \\
\text { Business developer }\end{array}$ \\
\hline Coy 8 & Information Technology & $\begin{array}{l}\text { Head of Venture Capital } \\
\text { IPR Manager }\end{array}$ \\
\hline Coy 9 & Research Instrument & Principal lecturer \\
\hline Coy 10 & Optics & Head of Venture Capital \\
\hline Coy 11 & Biotechnology & Head of Venture Capital \\
\hline Coy 12 & Biotechnology & Head of Venture Capital \\
\hline Coy 13 & Electronics & $\begin{array}{l}\text { Head of Venture Capital } \\
\text { IPR Manager }\end{array}$ \\
\hline Coy 14 & Chemical Production & CEO \\
\hline Coy 15 & Information Technology & $\begin{array}{l}\text { Head of Venture Capital } \\
\text { IPR Manager }\end{array}$ \\
\hline Coy 16 & Electronics & $\begin{array}{l}\text { Head of Venture Capital } \\
\text { IPR Manager }\end{array}$ \\
\hline Coy 17 & Research Instrument & $\begin{array}{l}\text { Head of Venture Capital } \\
\text { IPR Manager }\end{array}$ \\
\hline Coy 18 & Information Technology & $\begin{array}{l}\text { CEO } \\
\text { Head of Venture Capital } \\
\text { IPR Manager }\end{array}$ \\
\hline Coy 19 & Information Technology & $\begin{array}{l}\text { Head of Venture Capital } \\
\text { IPR Manager }\end{array}$ \\
\hline Coy 20 & Paper Production & $\begin{array}{l}\text { Head of Venture Capital } \\
\text { IPR Manager }\end{array}$ \\
\hline
\end{tabular}

\section{Empirical results}

The first result of the empirical study is related to the key activities performed within the different phases of commercialization. These results are explained separately for Corporate Ventures and Spin-offs in the following subsections:

\subsection{Corporate ventures}

Analyzing the readiness of the innovation projects, in all cases from the empirical setting, apart from having a clear value www.astesi.com proposition for customers and stakeholders, it was also necessary the achievement of first sales to obtain the interest of potential existing corporate units. This fact was enhanced when the innovation team had conducted real pilot programs.

The critical problem to overcome, as discovered across all cases, is the misfit between the R\&D project and the established corporate unit. The structure of the business unit was not prepared for the disruptive project that they received. The misfit has been discussed previously by scholars such as [13]. Also, exploitation units could lack crucial knowledge and resources to develop the innovation project. Collaboration from the business members and identifying an owner in the business unit who support and promote the project becomes one of the main challenges in full commercialization.

Another critical barrier for the survival of the transferred venture was the sales expectations the receiving business unit had on the innovation project and the lack of specific and flexible performance metrics to control the development of the venture, as previously discussed by [12].

The interviews and the data collected from the sample, allow us to identify different team activities which are crucial within the different phases of the transference of the projects to the exploitation business units, as well as the critical organizational factors influencing commercialization, providing generalization to the previous work of [73]. They are described as follows.

\subsubsection{Pre-transition phase}

\section{a) Achievement of first sales and running of pilot projects.}

Identifying leading customers willing to pay for the innovation is crucial in the maturity of the project. Another relevant key factor is obtaining real user traction, enhancing the interest of the corporate units, as enunciated by [73].

Moreover, the likelihood of conducting real pilot programs, and if possible, promoted by the customer enables the possibility of testing the hypotheses related to the projects linked to the particularities of the target market.

\section{b) Early-relation with the potential receiving business unit.}

Generating a relationship with the potential business unit and exchanging information concerning the $R \& D$ project seems to be crucial. The interaction between teams enables a better alignment with the corporate road map and enhances the involvement of the receiving team, as enunciated by $[12,29,36,39]$.

It becomes relevant to recognize potential marketers in the first stages of the R\&D process. These interactions could occur at managerial levels but also between the components of the teams.

This kind of relationship allows us to explain the value and potential of the innovation to gain the receiving team's trust. Communication should be transparent, transmitting the full knowledge obtained during the development phase, regarding the product, information about users and markets, including how the product has evolved and why.

Fostering communication between teams and the potential stakeholders for the innovation commercialization allows us to recognize possible future frictions, obtaining essential information to foresee how to overcome these barriers. 


\section{J. N. Cubero et al. / Advances in Science, Technology and Engineering Systems Journal Vol. 5, No. 2, 621-634 (2020)}

Finally, these cross-communications allow us to get more significant credibility for the innovation and future projects. It serves to identify key figures to obtain support from the base of the business unit, and from the management level, reaching a smoother integration.

\section{c) Search for champions and project support network.}

It has been observed in all the projects in the sample that senior management has played a supporting role, facilitating contacts and establishing bridges to look for potential marketers for the innovations. Identifying and involving a champion at the management level in the receiving team has been crucial to the success of the project. The role of informal networks has also been fundamental.

This championship perspective has been approached from the senior management perspective by $[36,41]$. [12,13] also pointed out the relevance of identifying an owner champion in the receiving business unit.

\subsubsection{Transition phase}

\section{a) Definition of the transition time.}

The different innovation unit managers underlined several tasks to get done to define the moment of transition:

- Once the R\&D project has reached the first sales with a customer, it is convenient to build customer loyalty and obtain new sales with similar clients to confirm the potential of the innovation through establishing a broader and more stable customer base.

- Another crucial indicator is to have a refined and tested business and operating model ready to scale, a reliable team, and a sales road map.

- Apart from having the product ready, it is also necessary to get ready a technology platform and the complementary services to run the innovation.

These activities have not been discussed in previous literature.

\section{b) Transfer of the $R \& D$ team to the receiving business unit}

In the projects of the sample in which part of the innovation team was transferred to transmit all the knowledge acquired during the research and development phases, a positive effect was observed in the transition. This specific activity has not been discussed previously by scholars.

\subsubsection{Post-transition phase}

\section{a) Performance metrics.}

Business units that incorporate innovations from corporate ventures must also exploit more incremental or mature projects. For this reason, specific KPI's must be established to apply to both the business unit teams and the disruptive innovation projects they will exploit. This concept has been previously enunciated by [12].

\subsubsection{Other auxiliary tasks to carry out}

Besides the similar activities identified in the projects, other patterns also appeared, described here as follows:

- Several unit managers highlighted the importance of identifying and incorporating different profiles from the business units to compose the needed team in the scaling up of the innovation. The search for these profiles aims not only to obtain the primary resources for growth but also to transform these future team members into potential champions of the innovation.

- Locating middle management champions at intermediate levels between the innovation team and the potential business unit was positive, acting as interfaces and transmitters of the benefits of the innovation.

- $\quad$ Another of the strategies recommended by different units and corporate innovation managers was to promote crossmovements of teams, incorporating temporary members from the innovation team into business units, enabling these profiles to approach the project from a business perspective, to detect possible future frictions.

These insights are new to literature.

\subsection{Spinoff}

It was noted during the interviews that technology entrepreneurs and business advisors acknowledged that certain activities have to be done before the actual commercialization and after it, defining pre-, on- and post-commercialization phases. Each phase has key activities; some of them previously not outlined in the scholarly works. The following section explains each of these critical activities according to the phases of commercialization.

\subsubsection{Pre-Commercialization Phase}

\section{a) Identification of innovation application.}

The study participants were able to identify an industrial process or sector where the innovation could be applied. They noted that the application should aim to solve a technical problem or social specific problem because its identification always enables commercializers to identify target markets for their innovations. This critical activity is also discussed by scholars such as [74]-[76].

\section{b) Professional protection of Intellectual Property.}

It is learned that IP protection happened after high-tech identified a business potential. The participants highlighted the importance of IP protection. They did not focus on ordinary protection, but rather professional protection. [54] emphasized the need for it.

\section{c) Establishing of the technology - business team.}

Previous works like [77,78] have stated that team formation plays an essential role in technology-based companies. The study participants plainly stated that a team should consist of someone who has a profound knowledge of the technology to be commercialized and someone who knows how to sell.

\section{d) Defining a clear target market.}

Scholars such as [45]-[47] have discussed this activity and concluded that marketization is a crucial pillar in commercialization. In the same perspective, the study participants shared that they succeeded in the commercialization because they were able to find a clear target market from the beginning of the commercialization challenge. 


\section{J. N. Cubero et al. / Advances in Science, Technology and Engineering Systems Journal Vol. 5, No. 2, 621-634 (2020)}

\section{e) Gathering sufficient market information.}

The study participants tried to gather sufficient market information. Participants stated that conducting market research ab initio is an essential step for commercialization success. They advised that commercializers should try to employ online and offline means to get market-related information on their target market. They added that the use of interpersonal networks to collect target market information played a significant role. This finding is in line with the recommendations of $[48,53,57]$.

f) Staying with the parent company.

Participants shared that they preferred to stay with their research institutions while developing their technologies (during their early businesses). Interviewees said that it provides an opportunity to bring existing networks and resources into play during pre-commercialization. [53] acknowledged this activity in their previous study.

\section{g) Identification of different business models.}

Scholars like [79]-[81] explained that business model development is essential. This empirical study found it to be one of the tools that helped to make a business successful. Interviewees pointed out that every commercializer should know and develop several business models in which the best options can be selected in the future.

\subsubsection{On-Commercialization Phase}

\section{a) Product simplification.}

Participants stressed that product simplification is a key factor in the on-commercialization phase, suggesting that a new product should be able to work with existing systems or use existing infrastructure. This activity has a relationship with the recommendations of $[43,48,49,77,78]$.

\section{b) Subcontracting / outsourcing.}

It was observed that the study participants preferred to work on their core technology and software aspects of the product while hardware and other parts were outsourced. They said that such a strategy enabled them to reach the market at the right time and to scale-up their production at a later stage of their company growth. This activity was also echoed by $[43,53]$.

\section{c) Having direct contact with end-users.}

The participants understood that the real information for validating and improving the product solution came from endusers. Therefore, this key activity is often done during commercialization, as it is stated by $[43,53,56,77,78]$.

\section{d) Testing and defining flexible business models.}

It is learned that the participants focused on testing while developing new business models.

\section{e) International awareness.}

The participants tried to attend international business events when developing their business models in order to improve awareness and develop networks. This activity has not yet been discussed by the previous scholars on the commercialization of innovations.

\section{f) Reference sales.}

The entrepreneur participants affirmed that one of their tasks during the commercialization stage is to make initial sales. They explained that this kind of sales is a pathway to sustainability. They shared that having references helps them to provide feedback for further development as well as create credibility for other clients and fundraising. This activity was discussed by [73] in the context of corporate ventures.

\section{g) Starting early internationalization.}

Study participants emphasized early internationalization during commercialization in order to develop a potential sales network.

\subsubsection{Post-Commercialization Phase}

\section{a) Getting feedback from initial buyers}

The study participants stressed that getting feedback is crucial for successful commercialization as a manner to satisfy customers as well as to offer more services, which in turn led to more revenue for the company. This activity is also outlined by $[51,56]$.

\section{b) Managing the supply chain}

As it can be noted from the pre- and on-commercialization stages, the study participants advised commercializers to subcontract or outsource the manufacturing process. This activity is related to the work of [55], where the commercialization process from the supply chain point of view is explained.

\section{Discussion and conclusions}

The case studies inform us about the different activities that corporate ventures and spin-offs carry out in order to confront the main challenges they encounter at pre-commercialization, oncommercialization and post-commercialization stages. The comparative analysis between the specific activities undertaken during the phases of commercialization allows us to define the main similarities and differences among the two structures upon scaling up the innovation project.

\subsection{Pre-transition/commercialization phase.}

Based on the analysis of collected data, the commitment of organizational leaders and stakeholders to commercialize the innovation appeared to be one of the most critical factors in both corporate ventures and spinoff cases. According to [6,77] for an innovation to be commercialized successfully, the organizational leaders and stakeholders must be committed to the process. The cases of this paper revealed that upper management support motivated the commitment of teams and project managers in commercialization teams. In the case of corporate ventures, early relations with the potential receiving business unit were crucial to search owners for the innovation project, as well as to get the involvement and support from all the layers in the commercialization unit. This network building could be obtained through bidirectional personnel exchange, education and training, cross-functional interfaces or horizontal interactions between teams. Endorsing the work of [8], the empirical results suggest that these activities contribute to balance the misfit (commitment, resources and objectives) among the $\mathrm{R} \& \mathrm{D}$ project and the existing 


\section{J. N. Cubero et al. / Advances in Science, Technology and Engineering Systems Journal Vol. 5, No. 2, 621-634 (2020)}

business unit, a key factor influencing the successful commercialization process.

Team formation at the moment of scaling up the innovation plays an essential role in technology-based companies, corroborating the work of [77]. The specific competencies and skills required for successful commercialization encourage corporate ventures and spin-offs to define and to form the right team to face this challenge with the appropriate resources of personnel. It was noted that a commercialization team consists of people from R\&D and business people, or even teams with dual technical and business development competencies. Furthermore, the project managers of these cases have the attributes of an intrapreneur, which is a closely related arrangement to the champion approach in corporate ventures. These managers can integrate technological knowledge, business expertise and user perspective. The same feature is evident among the serial entrepreneurs of the spin-off companies.

Team skills and work methodologies seem to be similar in both cases. The disruptive innovation team integrates cross profiles beyond technological qualifications. Customer research, communication and sales skills are the most valued competencies.

Collaboration or industrial networks also appeared to be another relevant factor for the transition of disruptive innovations from the parent organization to a spin-in unit or spin-off company. The cases of this paper showed that the availability of partners in and out company is a must to facilitate commercialization. It was learned that such collaboration motivated the spin-in unit to be active and it encouraged spinoff entrepreneurs to exert more effort.

Innovation project readiness. Besides these similarities, some divergences emerged from the cases studied. The innovation project seems to be more developed in the case of corporate ventures than in the case of spinoffs. Whereas in corporate ventures, the focus is on validating, demonstrating and creating credibility on the potential receiving business unit, spinoff tries to ascertain the real value or business potential of the innovation project by way of clarifying the target market. Spinoffs do so by gathering enough market information or developing several business models in which the best options can be selected in the future. Based on the collected data, in the corporate venture cases, the realization of first sales is a necessary, yet insufficient, condition for transference. It is required also to conduct pilot programs to demonstrate real traction and to maximize learning from real market situations.

This difference could be motivated by a more goal-minded orientation on the part of the project leader and team components of the corporate venture, even if they work separately from the exploitatory units of the parent company.

IP property. The analysis of the cases also reveals that corporate ventures are more financially supported and intellectual property protected thanks to their synergies with the corporate parent, while spin-offs must make an extra effort in IP protection and in search of funding and external partners.

\subsection{Transition/Commercialization phase}

Knowledge transference. In corporate venture cases, it is common that no one from the innovation team continues on the receiving business unit that will exploit the innovation project. Is for this reason that the study outlines the critical importance of making the right transmission of the complete knowledge acquired and of balancing out the shortcomings in terms of responsibilities within the receiving team, as well as their different motivations and goals, which confirms the previous work from [73], focused on telco industry. The information collected during the project development stage should always be transmitted to the exploitation team for a better understanding of the real needs of the users, the customer's feedbacks, the stakeholder's key information and the integration of all this knowledge into the innovation commercialization. The transference of members of the R\&D team helps to manage this knowledge.

Innovation project readiness. It can be noticed that some of the activities that spinoffs perform at the commercialization phase, such as product simplification, prototyping and testing with endusers or testing business models, are a "must" type of tasks that corporate ventures have to accomplish just before the transition time. For example, the innovation should have renewed the trust not only from users but also from clients, as well as have jumped to parallel market niches. The innovation project should also have a tested and refined business and operating model, a "go to market" strategy and the associated services developed to implement the innovation.

Resources. The limited resources that spin-offs have in comparison with corporate ventures make the former focus on their core business activities using subcontracting, while the latter devote their primary efforts to finding the right resources of personnel to exploit the disruptive innovation project.

Awareness and networks. Some of the activities that spin-offs perform at this phase are oriented to maximize awareness and to grow the sales network by the participation in business events, early internalization, creation of potential alliances and the definition and search for the right distribution channels. The synergies with the parent company in the case of corporate ventures help significantly when it comes to facing these challenges.

\subsection{Post-transition/commercialization phase}

It is during this phase when the approach from the two structures seems to be completely different, according to the analysis of the data collected from corporate ventures and spinoffs.

The following Table 5 summarizes the comparison between activities carried out by corporate ventures and spin-offs and the main challenges to overcome during the different phases of commercialization.

The insights gained from the spinoff cases reveal that even at this phase of post-commercialization, the process of refinement of the product is crucial, requiring the feedback from initial buyers.

Even if continuous refinement is also present in the mindset of corporate ventures, the activities performed by spinoffs during this phase are usually carried out by corporate ventures at the pretransition phase so that they can offer an optimized product to the receiving business unit. 


\section{J. N. Cubero et al. / Advances in Science, Technology and Engineering Systems Journal Vol. 5, No. 2, 621-634 (2020)}

Table 5. Comparison between corporate venture and spin-off activities and challenges during the different phases of commercialization.

\begin{tabular}{|c|c|c|c|c|c|}
\hline \multicolumn{3}{|c|}{ SPINOFF } & \multicolumn{3}{|c|}{$\begin{array}{l}\text { CORPORATE } \\
\text { VENTURE }\end{array}$} \\
\hline PHASE & \begin{tabular}{|l|} 
CHALLENGES TO \\
OVERCOME \\
\end{tabular} & ACTIVITIES & ACTIVITIES & $\begin{array}{l}\text { CHALLENGES TO } \\
\text { OVERCOME } \\
\end{array}$ & PHASE \\
\hline \multirow{5}{*}{ 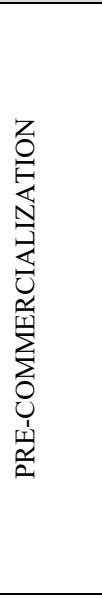 } & $\begin{array}{l}\text { GETTING COMMITMENT } \\
\text { FROM STAKEHOLDERS }\end{array}$ & $\begin{array}{l}\text { Identification of technological } \\
\text { opportunity } \\
\text { Application. Technical and economic } \\
\text { viability }\end{array}$ & $\begin{array}{l}\text { Early relations with potential business } \\
\text { units } \\
\text { Personal exchange and training } \\
\text { Cross-functional interfaces }\end{array}$ & $\begin{array}{l}\text { COMMITMENT FROM } \\
\text { BU. SEARCH FOR } \\
\text { CHAMPIONS }\end{array}$ & \multirow{5}{*}{ 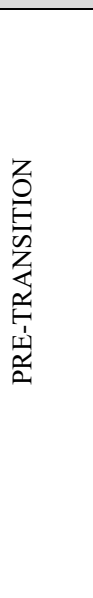 } \\
\hline & $\begin{array}{l}\text { ASCERTAINING } \\
\text { INNOVATION VALUE } \\
\text { AND BUSINESS } \\
\text { POTENTIAL }\end{array}$ & \begin{tabular}{|l} 
Targetting markets \\
Formulate different business models \\
Gathering enough market information
\end{tabular} & $\begin{array}{l}\text { Achieving first sales and running pilot } \\
\text { programs }\end{array}$ & $\begin{array}{l}\text { VALIDATION AND } \\
\text { DEMONSTRATE REAL } \\
\text { TRACTION }\end{array}$ & \\
\hline & & & Reduce all remaining uncertainties & $\begin{array}{l}\text { INNOVATION } \\
\text { PROJECT READINESS }\end{array}$ & \\
\hline & \begin{tabular}{|l|} 
TEAM LACK OF \\
RESOURCES AND \\
SKILLS \\
\end{tabular} & Formation of the commercialization team & $\begin{array}{l}\text { Definition and formation of the right } \\
\text { team }\end{array}$ & \begin{tabular}{|l|} 
TEAM LACK OF \\
RESOURCES AND \\
SKILLS \\
\end{tabular} & \\
\hline & $\begin{array}{l}\text { PROTECTION OF } \\
\text { INNOVATION }\end{array}$ & IP protection & & & \\
\hline \multirow{4}{*}{ 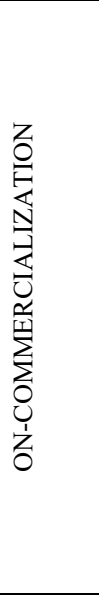 } & \begin{tabular}{|l} 
CONDITIONS FOR \\
COMMERCIALIZATION
\end{tabular} & $\begin{array}{l}\text { Reference sales } \\
\text { Product simplification. Ready or existing } \\
\text { Technology platform } \\
\text { Testing business models } \\
\text { Prototype and testing with end-users. } \\
\text { Final validation }\end{array}$ & $\begin{array}{l}\text { Renew sales and open new niches } \\
\text { Clear operating model and technology } \\
\text { platform } \\
\text { technology platform. Complementary } \\
\text { services } \\
\text { Ready business model }\end{array}$ & $\begin{array}{l}\text { CONDITIONS FOR } \\
\text { TRANSITION TIMING }\end{array}$ & \multirow{4}{*}{ 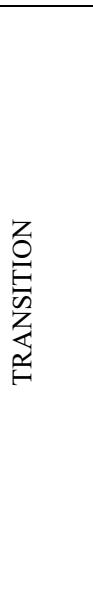 } \\
\hline & LACK OF RESOURCES & Subcontracting & Search for the right personal resources & $\begin{array}{l}\text { RESOURCES } \\
\text { LEVERAGING }\end{array}$ & \\
\hline & $\begin{array}{l}\text { AWARENESS AND } \\
\text { SALES NETWORK }\end{array}$ & \begin{tabular}{|l} 
Participation in business events \\
\\
Internationalization \\
Creation of potential alliances \\
Searching for distribution channels \\
\end{tabular} & Synergies with corporate parent & $\begin{array}{l}\text { AWARENESS AND } \\
\text { SALES NETWORK }\end{array}$ & \\
\hline & & & $\begin{array}{l}\text { Team transference for knowledge } \\
\text { transferences }\end{array}$ & $\begin{array}{l}\text { KNOWLEDGE } \\
\text { MANAGEMENT }\end{array}$ & \\
\hline \multirow{5}{*}{ 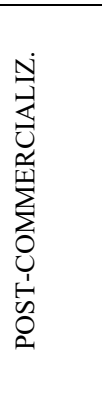 } & PROMOTING SPINOFF & $\begin{array}{l}\text { Product launching and post launching. } \\
\text { Market assessment }\end{array}$ & & & \multirow{5}{*}{ 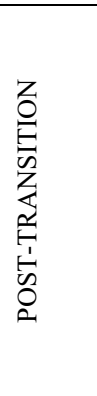 } \\
\hline & $\begin{array}{l}\text { REFINING INNOVATION } \\
\text { PROJECT }\end{array}$ & Getting back from initial buyers & & & \\
\hline & $\begin{array}{l}\text { OPTIMIZATION VALUE } \\
\text { CHAIN }\end{array}$ & Managing supply chain & & & \\
\hline & & & Defining specific performance metrics & $\begin{array}{l}\text { BALANCE } \\
\text { EXPLORATION \& } \\
\text { EXPLOITATION } \\
\text { PROJECTS } \\
\end{array}$ & \\
\hline & & & Searching for partial autonomy & $\begin{array}{l}\text { KEEPING CV } \\
\text { MINDSET }\end{array}$ & \\
\hline
\end{tabular}

The size and lack of resources that spinoffs have, push these kinds of organizations to focus part of their specific activities on this phase, in order to define and develop the supply chain, the commercialization, and the launching process that will help to scale up the innovation.

The study shows that in the cases of innovation projects from corporate ventures transferred to a business unit, they focus on keeping some autonomy of criteria and mindset (coming from the R\&D team) in order to optimize the scaling up of the innovation in the corporate parent. Also, participants asked to define specific performance metrics that could be applied to the commercialization team in order to be able to balance explorative and exploitative projects.

\section{Contributions and limitations}

The main contribution of this article is that it provides the key commercialization activities for the corporate venture and spinoff. It outlines that team formation, network development, and early relations with potential comercializers and stakeholders are the important commercialization activities that the disruptive innovations require regardless the commercialization approach. Additionally, the article outlines that there are divergences between the corporate venture and the spinoff approach. These divergences include innovation readiness, knowledge management or the approach to the post-transition phase. 
Another contribution of the article is the comparison of both corporate ventures and spinoff. Even though there are many literary works on both approaches, there is no scholarly work yet that compares them. This comparison shows that both approaches have various phases and each of the phases has several activities. It also provides an in-depth understanding of both approaches on the commercialization of disruptive innovation, stressing the common challenges corporate venture and spinoff face, as follows: ascertaining and validating the business potential of the innovation, getting the commitment from the corporate parent and stakeholders, overcoming the lack of resources and obtaining awareness and credibility from market and stakeholders.

Additionally, the article contributes to the practice by enhancing understanding of the commercialization process of disruptive innovation via the corporate ventures and spinoffs approaches. It outlines some key barriers that the practitioner might face during the process, as the misfit between the R\&D project and the established corporate unit, the lack of specific and flexible performance metrics to control the evolution of the project or how to define the right conditions for the commercialization of the innovation

However, the article has some limitations, defining at the same time fields for future research. Firstly, the case study method applied in the article inherited the problem of generalization, as it is usually the case. This makes the findings of this article to be limited with regards to generalization. Although the findings are generic, which means they can be generalized, yet it is recommended that the findings' generalization is determined by the nature of the concerned technology, its industry and its target market.

Furthermore, this empirical research of the article does not incorporate the perspective of the managers of the business units that receive the innovation. Obtaining the vision from these profiles will enrich the data gathered regarding the research questions.

Further, the collected data were gathered from different countries. The corporate venture data were collected in Spain, Germany, and the UK, whereas spinoff data were collected in Finland. These countries have similarities and differences, and the latter might affect the findings of the article. Therefore, future studies could examine corporate venture and spin-off activities in the same country and the same industry.

Lastly, the findings of the article need to be confirmed through further research, something that creates room for future studies. For instance, it would be good to have a quantitative study where the identified activities are tested or a study of how the key activities impact the commercialization of technology-based companies' high-tech.

\section{Conflict of Interest}

The authors declare no conflict of interest.

\section{Acknowledgment}

The corresponding author would like to thank the Design Processes Research Group from EINA University Center of Design and Arts (Autonomous University of Barcelona) for their support.

\section{References}

[1] C. Lettl, "User involvement competence for radical innovation", J. Eng. Technol. $\quad$ Manage., 24(1-2), 53-75, 2007. https://doi.org/10.1016/j.jengtecman.2007.01.004

[2] J. Nieto Cubero and C. Consolación Segura, "The Role Teams and Organizational Factors Play in Disruptive Innovations in Ambidextrous Organizations" in the 2019 ICE/ITMC International Conference on Engineering, Technology and Innovation, Valbonne Sophia-Antipolis, France, 2019, https://doi.org/10.1109/ICE.2019.8792627

[3] S.A.Gbadegeshin, "The Commercialization Process of High Technologies: Case Studies from ICT, Cleantech and Life Sciences Industries" Ph.D. Thesis, University of Turku, Finland, 2019.

[4] X.M.Song and M.M.Montoya-Weiss, "Critical development activities for really new versus incremental products", J. Prod. Innovat. Manag., 15(2), 124-135, 1998. https://doi.org/10.1111/1540-5885.1520124

[5] C.M. McDermott and G.C. O'Connor, "Managing radical innovation: an overview of emergent strategy issues", J. Prod. Innovat. Manag., 19, 424438, 2001. https://doi.org/10.1111/1540-5885.1960424

[6] S.A. Gbadegeshin, S.A, "Commercialization process of high technologies: case study of finnish university spin-off", Acad. Entrep. J., 23(2), 122, 2017.

[7] S.A. Gbadegeshin, "Stating best commercialization method: An unanswered question from scholars and practitioners", Int. J. Eco. Eng. Manag., 11(5), 1088-1094, 2017.

[8] M.A. Kirchberger, and L. Pohl, "Technology commercialization: a literature review of success factors and antecedents across different contexts", J. Technol. Transfer, 41(5), 1077-1112, 2016. https://doi.org/10.1007/s10961016-9486-3

[9] K. Hindle and J. Yencken, "Public research commercialization, entrepreneurship and new technology-based firms: an integrated model", Technovation, 24(10), 793-803, 2004. https://doi.org/10.1016/S01664972(03)00023-3

[10] R.A.Burgelman and L.R. Sayles, "Inside corporate innovation: strategy, structure and managerial skills", Management, 18(2), 179-185, 1986. https://doi.org/10.3917/mana.182.0179

[11] S.A. Hill and J. Birkinshaw, "Strategy-organization configurations in corporate venture units: Impact on performance and survival", J. Bus. Venturing, 23(4), 423-444, 2008 https://doi.org/10.1016/j.jbusvent.2007.04.001

[12] E. van Burg, S. de Jager, I.M.M.J. Reymen and M.Cloodt, " Design principles for corporate venture transition processes in established technology firms", R\&D Manage., 42(5), 455-472, 2012. https://doi.org/10.1111/j.1467-9310.2012.00695.x

[13] M.P. Rice, R. Leifer, and G.C. O'Connor, "Commercializing discontinuous innovations: bridging the gap from discontinuous innovation project to operations", IEEE T. Eng. Manage., 49(4), 330-340, 2002. doi: 10.1109/TEM.2002.806721

[14] R. Garcia and R. Calantone, "A critical look at technological innovation typology and innovativeness terminology: a literature review", J. Prod. Innovat. Manag., 19(2), 110-132, 2002. https://doi.org/10.1111/15405885.1920110

[15] V. Govindarajan and P.K. Kopalle, "The usefulness of measuring disruptiveness of innovations ex-post in making ex-ante predictions", J. Prod. Innovat. Manag., 23, 12-18, 2006. https://doi.org/10.1111/j.15405885.2005.00176.x

[16] D. Dougherty, "Understanding new markets for new products", Strateg. Manage. J., 11, 59-78, 1990. https://doi.org/ 10.1108/00251749810223592

[17] R.A. Burgelman, "A process model of internal corporate venturing in the diversified major firm", Admin. Sci. Quart., 28(2), 223-244, 1983. https://doi.org/10.2307/2392619

[18] S. Ford, E. Garnsey and D. Probert, "Evolving corporate entrepreneurship strategy: technology incubation at Philips", R\&D Manage., 40(1), 81-90, 2010. https://doi.org/10.1111/j.1467-9310.2009.00580.x

[19] G.C. O'Connor, and R. de Martino, "Organizing for radical innovation: An exploratory study of the structural aspects of RI management systems of large established firms", J. Prod. Innovat. Manag., 23, 475-497, 2006. https://doi.org/10.1111/j.1540-5885.2006. 00219.x

[20] M.L. Tushman and C.A. O'Reilly, "Ambidextrous organizations: managing evolutionary and revolutionary change", Calif. Manage. Rev., 38(4), 8-30, 1996. https://doi.org/10.2307/41165852

[21] D.A. Levinthal and J.G. March, "The myopia of learning", Strateg. Manage. J., 14, 95-112, 1993. https://doi.org/10.1002/smj.4250141009

[22] H. Chesbrough, and C.L. Tucci, "Corporate Venture Capital in the Context of Corporate Innovation”. EPFL Working Paper, Lausanne, 2005. 


\section{J. N. Cubero et al. / Advances in Science, Technology and Engineering Systems Journal Vol. 5, No. 2, 621-634 (2020)}

[23] R.G. McGrath, "Exploratory learning, innovative capacity, and managerial oversight", Acad. Manag. J., 44(1), 118-131, 2001. https://doi.org/10.5465/3069340

[24] N. Thornberry, "Corporate entrepreneurship: Antidote or oxymoron?", Eur. Manag. J., 19(5), 526-533, 2001. https://doi.org/10.1016/S02632373(01)00066-4

[25] E. G. Carayannis, E.M. Rogers, K. Kurihara and M.M. Allbritton, "Hightechnology spin-offs from government, R\&D laboratories and research universities", Technovation, 18(1), 1-11, 1998. https://doi.org/10.1016/S0166-4972(97)00101-6

[26] F. Pirnay, B. Surlemont and F. Nlemvo, "Toward a typology of university spin-offs", Small Bus. Eco., 21(4), 355-369, 2003. https://doi.org/10.1023/A:1026167105153

[27] S. Shane, Academic Entrepreneurship: University Spin-offs and Wealth Creation., UK, Edward Elgar Publishing Ltd, 2004.

[28] G.S. Lynn and A.E. Akgün, "Innovation strategies under uncertainty: A contingency approach for new product development", Eng. Manag. J., 10(3), 11-18, 1998. https://doi.org/10.1080/10429247.1998.11414991

[29] O. Gassmann, B. Widenmayer and M. Zeschky, "Implementing radical innovation in the business: the role of transition modes in large firms", R\&D Manage., 42(2), 120-13, 2012. https://doi.org/10.1111/j.14679310.2011.00670.x

[30] R. Chandy and G. Tellis, "The incumbent's curse? incumbency, size, and radical product innovation", J. Marketing, 64(3), 2000. https://doi.org/ 10.1509/jmkg.64.3.1.18033

[31] G.C. O'Connor, R. Hendricks and M.P. Rice, "Assessing transition readiness for radical innovation", Res. Tech. Manage., 45(6), 50-56, 2002. https://doi.org/10.1080/08956308.2002.11671533

[32] D. Clausing and M. Holmes, "Technology readiness", Res. Tech. Manag., 53(4), 52-59, 2010. https://doi.org/10.1080/08956308.2010.11657640

[33] J.C. Mankins, "Technology readiness and risk assessments: A new approach", Acta Astronaut., 65(9), 1208-1215, 2009. https://doi.org/10.1016/j.actaastro.2009.03.059

[34] C.A. O'Reilly and M.L. Tushman "The ambidextrous organization", Harvard Bus. Rev., 82(4), 74-81, 2004.

[35] G.C. Gilbert, "Change in the presence of residual fit: Can competing frames coexist?", Organ. Sci., 17(1), 150-167, 2006. https://doi.org/10.1287/orsc. 1050.0160

[36] J.J.P. Jansen, M.P. Tempelaar, F.A.J. van den Bosch and H.W. Volberda, "Structural differentiation and ambidexterity: The mediating role of integration mechanisms", Organ. Sci., 20(4), 797-811, 2009. https://doi.org/10.1287/orsc. 1080.0415

[37] C. Andriopoulos and M.W. Lewis, "Exploitation-exploration tensions and organizational ambidexterity: Managing paradoxes of innovation", Organ. Sci., Special Issue on Ambidextrous Organizations, 20(4), 696-717, 2009. https://doi.org/10.1287/orsc. 1080.0406

[38] O.P. Kauppila, "Creating ambidexterity by integrating and balancing structurally separate inter-organizational partnerships", Strateg. Organ., 8(4), 283-312, 2010. https://doi.org/10.1177\%2F1476127010387409

[39] S. Raisch and M.L. Tushman, "Growing new corporate businesses: From initiation to graduation", Organ. Sci., 27(5), 1237-57, 2016. https://doi.org/10.1287/orsc.2016.1081

[40] D.A. Garvin and L.C. Levesque, "Meeting the challenge of corporate entrepreneurship", Harvard Bus. Rev., 84(10), 102-112, 2006.

[41] M.L. Tushman and D. Lavie, "Exploration and exploitation within and across organizations", Acad. Manag. Ann., 4(1), 109-155, 2010. https://doi.org/10.5465/19416521003691287

[42] M. Steffensen, E.M. Rogers and K. Speakman, "Spin-offs from research centers at a research university”, J. Bus. Venturing, 15(1), 93-111, 1998. https://doi.org/10.1016/s0883-9026(98)00006-8

[43] F. Frattini, A. De Massis, V. Chiesa, L. Cassia and G. Campopiano, "Bringing to market technological innovation: What distinguishes success from failure", Int. J. Eng. Bus. Manag., 4(15), 1 -11, 2012. https://doi.org/10.1111/j.1540-5885.2006.00220.x

[44] T. M. Nevens, G. L. Summe, and B. Uttal, "Commercializing technology: What the best companies do", Harvard Bus. Rev., 64(8), 154-163, 1990. https://doi.org/10.1108/eb054310

[45] J.S. Gans and S. Stern, "The product market and the market for "ideas": commercialization strategies for technology entrepreneurs", Res. Policy, 32(2), 333-350, 2003. https://dx.doi.org/10.2139/ssrn.317219

[46] J. Pellikka and P. Malinen, "Developing Commercialisation of Innovation in High Technology Industries - Regional Perspective", in 2011 56th International Council for Small Business (ICSB), Stockholm, Sweden, June $15-18,2011$.

[47] P. Valiauga, "Commercialization of High-tech Radical Innovations: Case Studies of X-ray Imaging Technologies." in 2013 paper presented at the
Aalto University School of Science, Finland, May 16, 2013. http://noppa.aalto.fi/noppa/kurssi/tu-22.1500/luennot/TU-22_1500_povilas

[48] S.P. Nichols, "Module 1: An Introduction to Commercialization of Science and Technology. Converting Technology to Wealth Workshop". Austin, TX: IC2 Institute, The University of Texas at Austin http://ut.gtrade.or.kr/inc/download.asp?key $=5288$

[49] A. Dhebar, "Bringing new high-technology products to market: Six perils awaiting marketers", Bus. Horiz., 59, 713-722, 2016. https://doi.org/10.1016/j.bushor.2016.08.006

[50] A.D. Chandler, "Commercializing high-technology industries", Bus. Hist. Rev., 79(3), 595-604, 2005. https://doi.org/ 10.1017/S0007680500081460

[51] A.C. Fletcher and P.E. Bourne, "Ten simple rules to commercialize scientific research", PLoS Comput. Biol., 8(9), e1002712, 2012. https://doi.org/10.1371/journal.pcbi.1002712

[52] S. F. Slater and J. J. Mohr, "Successful development and commercialization of technological innovation: insights based on strategy type", J. Prod. Innovat. Manag., 23(1), 26-33, 2006. https://doi.org/10.1111/j.15405885.2005.00178.x

[53] E. Maine and E. Garnsey, "The commercialization environment of advanced materials ventures", Int. J. Technol. Manage., 39(1/2), 49 -71, 2012. https://doi.org/ 10.1504/IJTM.2007.013440

[54] J. E. Amadi-Echendu and R. T. Rasetlola, "Technology Commercialization Factors, Frameworks and Models" in 2011 IEEE/ITMC Conference, 144148, 2011.

[55] D. S. Rogers, D. M. Lambert, and A. M. Knemeyer, "The Product Development and Commercialisation Process", Int. J. Logist. Manag., 15(1), 43 - 56, 2004. https://doi.org/10.1108/09574090410700220

[56] J. B. Pietzsch, L. A. Shluzas, M. E. Paté-Cornell, P. G. Yock and J. H. Linehan, "Stage-gate process for the development of medical devices", J. Med. Devices, 3(021004), $1-15, \quad 2009$ https://doi.org/10.1016/j.technovation.2017.03.003

[57] T. Elfring and N. Foss, "Corporate Renewal Through Internal Venturing and Spinn-offs: Perspectives from Organizational Economics", No 97-7, IVS/CBS Working Papers, 97-7, 1997.

[58] B. L. Golish, M.E. Besterfield-Sacre and L. J. Shuman, "Comparing Academic and Corporate Technology Development Processes", J. Prod. Innovat. Manag., 25(1), 47-62, 2008. https://doi.org/10.1111/j.15405885.2007.00282.x

[59] P.P. Georgallis and R. Durand, "Achieving High Growth in Policy Dependent Industries: Differences between Startups and Corporate-Backed Ventures", Long Range Plann., 50(4), 487-500, 2017. https://doi.org/10.1016/j.lrp.2016.06.005

[60] K. Wennberg, J. Wiklund and M. Wright, "The Effectiveness of University Knowledge Spillovers: Performance Differences between University Spinoffs and Corporate Spinoffs", Res. Policy, 40(8), 1128-1143, 2011. https://doi.org/10.1016/j.respol.2011.05.014

[61] S.A. Zahra, E. Van de Velde and B. Larraneta, "Knowledge Conversion Capability and the Growth of Corporate and University Spinoffs", Ind. Corp Change, 16(4), 569-608, 2007. https://doi.org/10.1093/icc/dtm018

[62] R. C. Shrader and M. Simon, "Corporate Versus Independent new Ventures: Resource, Strategy, and Performance Differences", J. Bus. Venturing, 12(1), 47-66, 1997. https://doi.org/10.1016/S0883-9026(96)00053-5

[63] T. Bager, H. Ottosson and T. Schøtt, "Intrapreneurs, Entrepreneurs and Spinoff Entrepreneurs: Similarities and differences", Int. Small. Bus. J., 10(3), 2010. https://doi.org 10.1504/IJESB.2010.033572

[64] R.K. Yin, Case Study Research, Thousand Oaks, CA: Sage Publications, 1994.

[65] E. Danneels, "Disruptive technology reconsidered: a critique and research agenda", J. Prod. Innovat. Manag., 21(4), 246-258, 2004. https://doi.org/10.1111/j.0737-6782.2004.00076.x

[66] K.M. Eisenhardt, "Building theories from case study research", Acad. Manag. Rev., 14(4), 532-550, 1989. https://doi.org/ 10.2307/258557

[67] D. E. Gray, Doing Research in the Real World, Chapter 2: Theoretical Perspectives and Research Methodologies, USA: Sage Publications, 2013.

[68] J. W. Creswell, Research Design: Qualitative, Quantitative and Mixed Methods Approaches. 3rd Ed., United Kingdom, London: Sage Publication, 2009.

[69] P. Eriksson and A. Kovalainen, Qualitative Methods in Business Research, 1st Ed., United Kingdom, London: Sage Publications, 2008.

[70] S. Rajasekar, P. Philominathan and V. Chinnathambi, V.Rese. Method., 2016. http://arxiv.org/pdf/physics/0601009.pdf

[71] N. Denzin and Y. Lincoln, Handbook of Qualitative Research, United Kingdom, London: Sage Publications, 2000.

[72] J.M. Corbin and A. Strauss, Basics of Qualitative Research, 3rd Ed., Thousands Oaks: Sage Publications, 2008 
[73] J. Nieto, "Managing Integration of Disruptive Innovations in Ambidextrous Organizations", in 2018 ISPIM Innovation Conference, Stockholm, Innovation, the Name of the Game, Stockholm: LUT Scientific and Expertise Publications, 2018.

[74] N. Abd Rahima, Z. B. Mohamed, and A. Amrin, "Commercialization of emerging technology: The role of academic entrepreneur", Soc. Behav. Sci., 169, 53 - 60, 2005. https://doi.org/10.1016/j.sbspro.2015.01.285

[75] E. W. Eldred and M. E. McGrath, "Commercializing new technology", Res. Tech. Manag., 40(1), 41-47, 1997. https://doi.org/10.1080/08956308.1997.11671102

[76] J. E. Amadi-Echendu and A. John, "On the Commercialization of Trailing Knowledge and IP", in 2008 PICMET'08 Conference, Cape Town. Paper ID: 08R0018, 2008.

[77] A. Al Natsheh, S.A. Gbadegeshin, A. Rimpiläinen and T. Mainela, "Technology-based entrepreneurship: measurement technology perspective", Int. J. Res. Bus., 2(9), 26 - 42, 2013.

[78] J. Che and R. Panda, "Review: Commercialisation of Piezoelectric Single Crystals for Medical Imaging Applications", in 2005 IEEE Ultrasonics Symposium, 235-240, 2005.

[79] H. Chesbrough, "Business model innovation: opportunities and barriers", Long Range Plann., 43(2), 354-363, 2010. https://doi.org/10.1016/j.lrp.2009.07.010

[80] D.J. Teece, "Business models, business strategy and innovation", Long Range Plann., 43(2), 2010. https://doi.org/10.1016/j.lrp.2009.07.003

[81] C. Zott, R. Amit and L. Massa, "The business model: recent developments and future research", J. Manage., 37(4), 1019-1042, 2011. https://doi.org/10.1177\%2F0149206311406265 